${ }^{1}$ Boivin, A., Vendrely, R., and Vendrely, C., C.r. hebd. Séanc. Acad. Sci. Paris, 226, 1061 (1948).

2 Mirsky, A. E., and Ris, H., Nature, 163, 666 (1949).

${ }^{3}$ Rudkin, G. T., Genetics, Suppl. 61, 1 (1969).

4 Lima-de-Faria, A., in Handbook of Molecular Cytology (edit. by Lima-de-Faria, A.), 277 (North-Holland, Amsterdam and London, 1969).

s Hale, A. J., J. Path, Bact., 85, 311 (1963).

- Garcia, A. M., Acta Histochem., 17, 230 (1964).

7 Deitch, D. A., Wagner, D., and Richart, R. M., J. Histochem. Cytochem., 16, 371 (1967).

8 Mayall, B. H., J. Histochem. Cytochem., 17, 249 (1969).

- Sullivan, P. A., and Garcia, M., Acta Cytol., 14, 104 (1970).

${ }^{10}$ Gottlieb-Rosenkrantz, P., and O'Brien, R., J. Histochem. Cytochem., 19, 232 (1971).

11 James, J., Acta Cytol., 17, 15 (1973).

12 Pearse, A. G. E., Histochemistry, (Churchill, London, 1960).

${ }^{13}$ Goldstein, D. J., J. Microsc., 92, 1 (1970).

14 Goldstein, D. J., J. Microsc., 93, 15 (1971).

\section{C-type viral particles in a urinary bladder neoplasm induced by Schistosoma haematobium}

NEOPLASMS may be induced in nonhuman primates after infection with Schistosoma haematobium (refs 1 and 2 and unpublished results of R. E. K., A. W. Cheever, B. J. Myers, S. W. Young and J. A. Moore). After various times, masses develop within the urinary bladders of the hosts, ranging from hyperplasia to papillary carcinoma as determined histopathologically. Although the basic mechanism of tumour induction in such cases is not known, the many factors involved could include stimulation of endogenous virus infections. It is therefore interesting that we have now found C-type viral particles in one out of four papillary carcinomas of capuchin (Cebus sp.) monkeys experimentally infected with $S$. haematobium. None were seen in two infected animals that developed only hyperplasia and squamous metaplasia. Previous examination of normal bladder tissue has failed to demonstrate similar C-type viruses. For electron microscopy and infection of the animals with $S$. haematobium we used published methods ${ }^{1,3,4}$. The bladders were taken from monkeys previously infected with $S$. haematobium (Table 1). Histological evaluation based on examination of biopsy samples is also provided (Table 1).

Table 1 Histological evaluation of bladders of capuchin monkeys infected with $S$. haematobium $\dagger$

\begin{tabular}{|c|c|c|c|c|c|}
\hline $\begin{array}{l}\text { Animal } \\
\text { No./sex }\end{array}$ & $\begin{array}{l}\text { No. of } \\
\text { cercariae } \\
\text { inoculated }\end{array}$ & $\begin{array}{l}\text { Duration } \\
\text { of infection } \\
\text { (weeks) }\end{array}$ & $\begin{array}{l}\text { Egg pa } \\
\text { Faeces }\end{array}$ & $\begin{array}{l}\text { Ussage* } \\
\text { Urine }\end{array}$ & \\
\hline $\begin{array}{l}\text { CA } 23 \mathrm{M} \\
\text { CA } 62 \mathrm{~F}\end{array}$ & $\begin{array}{l}2,000 \\
2,000\end{array}$ & $\begin{array}{l}113 \\
109\end{array}$ & t & $\begin{array}{l}++ \\
+\end{array}$ & $\begin{array}{l}\text { Hyperplasia } \\
\text { Slight hyper- } \\
\text { plasia, and } \\
\text { squam ous } \\
\text { metaplasia }\end{array}$ \\
\hline CA $64 \mathrm{M}$ & 1,000 & 109 & + & 0 & $\begin{array}{l}\text { Papillary carci- } \\
\text { noma }\end{array}$ \\
\hline CA $67 \mathrm{M}$ & 2,000 & 109 & $+t$ & + & $\begin{array}{l}\text { Papillary carci- } \\
\text { nom a and } \\
\text { s qua m o u s } \\
\text { metaplasia }\end{array}$ \\
\hline CA $68 \mathrm{~F}$ & 2,000 & 109 & + & + & $\begin{array}{l}\text { Papillary carci- } \\
\text { nom a a n } \\
\text { s quam ou s } \\
\text { metaplasia }\end{array}$ \\
\hline CA $70 \mathrm{M}$ & 1,000 & 111 & + & +++ & $\begin{array}{l}\text { Papillary carci- } \\
\text { noma and } \\
\text { s qua mo us } \\
\text { metaplasia }\end{array}$ \\
\hline
\end{tabular}

$*+,++,+++$, Indicate few, moderate numbers, or many eggs in samples 1-3 weeks before indicated duration of infection.

† Carried out by Dr A. W. Cheever, National Institute of Allergy and Infectious Diseases.
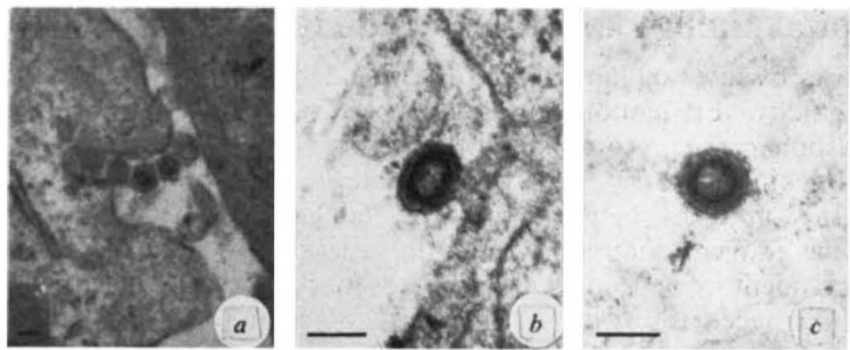

Fig. $1 a$, Neoplastic transitional epithelium from urinary bladder of monkey No. 70 with typical mature C-type viral particles in extracellular spaces. $b$, C-type particle budding from plasma membrane. $c$, Immature C-type particles in extracellular space. (Scale: $100 \mathrm{~nm}$.)

Figure 1 shows electron microscopic evidence of C-type viruses at various stages of maturation associated with transitional epithelial cells in the bladder carcinoma of capuchin No. 70. This tissue was the same as that examined by light microscopy. Viral particles were readily observable throughout the transitional epithelial areas, but were absent in the loose connective and smooth muscle layers. It should be emphasised that although one of the six monkeys examined was positive, this was the animal with moderate atypia. As Table 1 shows, this animal was also passing the highest number of eggs in its urine, an indication of involvement of the bladder. Control tissue, that is bladders of animals not infected with Schistosoma as well as those with minimal or minor involvement of the bladder, has so far failed to disclose the presence of C-type particles.

No definitive conclusions concerning the aetiology of bladder cancer can be drawn from these observations, but they do offer an intriguing approach for further study. Bladder cancers of nonhuman primates are extremely rare', and while coincidence cannot be ruled out, several other considerations must be examined. It has been suggested that all primates, like some other animal species, contain endogenous C-type particles ${ }^{6,7}$. Is the schistosome the cause or is it the triggering mechanism? On the other hand, is this tumour development due to an exogenous agent, which is carried by the parasite?

We thank Messrs Jerry A. Moore and Al Bodenman for assistance. This study was funded in part by the Virus Cancer Program, National Cancer Institute, the US Public Health Service, US-Japan Cooperative Medical Science Program administered by US Public Health Service and the World Health Organisation.
S. S. KALter
R. E. KUNTZ
R. L. Heberling
R. J. HeLMKe
G. C. SMith

Southwest Foundation for Research and Education,

PO Box 28147,

San Antonio, Texas 78284

Received May 6; revised June 18, 1974.

${ }^{1}$ Kuntz, R. E., Cheever, A. W., and Myers, B. J., J. natn. Cancer Inst., 48, 223 (1972).

2 Kuntz, R. E., and Myers, B. J., in Medical Primatology 1972 (edit. by Goldsmith, E. I., and Moor-Jankowski, J.) (Karger, Basel, 1972).

${ }^{3}$ Kalter, S. S., Helmke, R. J., Panigel, M., Heberling, R. L., Felsburg, P. J., and Axelrod, L. R., Science, 179, 1332 (1973).

- Kalter, S. S., Helmke, R. J., Heberling, R. L., Panigel, M., Fowler, A. K., Strickland, J. E., and Hellman, A., J. natn. Cancer Insi., 50, 1081 (1973).

'Chesney, C. F., and Allen, J. R., Lab. Animal Sci., 23, 716 (1973).

" Lieber, M. M., Benveniste, R. E., Livingston, D. M., and Todaro, G. J., Science, 182, 56 (1973).

Kalter, S. S., Heberling, R. L., Hellman, A., Todaro, G. J., and Panigel, M., Proc. Roy. Soc. Med. (in the press). 